\title{
Antimicrobial Activities of Syzygium aromaticum (L.) Merr. \& L.M. Perry (Myrtaceae) Fruit Extracts on Six Standard Microorganisms and Their Clinical Counterpart
}

\author{
Y.-G. Afanyibo ${ }^{1,2,3^{*}}$, K. Anani ${ }^{2,4}$, K. Esseh ${ }^{1,2}$, Y. Sadji ${ }^{3}$, K. Idoh ${ }^{1,2}$, K. Koudouvo ${ }^{1,2}$, \\ A. Agbonon 1,2, Y. Améyapoh ${ }^{2,4}$, K. Tozo5, M. Gbeassor ${ }^{1,2}$ \\ ${ }^{1}$ Laboratory of Physiology-Pharmacology, Faculty of Sciences (FDS), University of Lomé (UL), Lomé, Togo \\ ${ }^{2}$ Center for Research and Training on Medicinal Plants (CERFOPLAM), Lomé, Togo \\ ${ }^{3}$ Laboratory of Bacteriology, The National Institute of Hygiene (INH) of Lomé, Lomé, Togo \\ ${ }^{4}$ Higher School of Biological and Food Techniques (ESTBA), Lomé, Togo \\ ${ }^{5}$ Plant Biotechnology Laboratory, Department of Botany, FDS, Lomé, Togo \\ Email: *yaogameli@yahoo.fr
}

How to cite this paper: Afanyibo, Y.-G., Anani, K., Esseh, K., Sadji, Y., Idoh, K., Koudouvo, K., Agbonon, A., Améyapoh, Y., Tozo, K. and Gbeassor, M. (2018) Antimicrobial Activities of Syzygium aromaticum (L.) Merr. \& L.M. Perry (Myrtaceae) Fruit Extracts on Six Standard Microorganisms and Their Clinical Counterpart. Open Access Library Journal, 5: e4951. https://doi.org/10.4236/oalib.1104951

Received: September 30, 2018

Accepted: December 26, 2018

Published: December 29, 2018

Copyright $\odot 2018$ by authors and Open Access Library Inc.

This work is licensed under the Creative Commons Attribution International License (CC BY 4.0).

http://creativecommons.org/licenses/by/4.0/

\section{c) (i) Open Access}

\begin{abstract}
Syzygium aromaticum is used in combination with other plants as an alcoholic infusion by traditional practitioners to treat infections. It has been selected for evaluation for its antimicrobial properties to justify its use in traditional pharmacopoeia. The fruits were used as plant material while the microbial germs consisted of six reference strains: Escherichia coli ATCC 25922, Staphylococcus aureus ATCC 29213, Salmonella typhimurium ATCC 14028, Pseudomonas aeruginosa ATCC 27853, Shigella flexneri ATCC 12022, Candida albicans ATCC 35659 and their clinical counterparts. The extracts were obtained by aqueous decoction, hydroethanolic and ethanolic macerations. The phytochemical screening was performed by chemical staining tests. The antibiotic susceptibility test was performed using the well diffusion method and the MIC and MBC or MFC were determined using the 96-well microplate dilution method. The results showed that $66.67 \%$ of the strains tested were sensitive to the aqueous extract with inhibition diameters ranging from 15 to $21 \mathrm{~mm}$ and MIC and MCB or MFC between $0.0976-0.3906 \mathrm{mg} / \mathrm{mL}$ and $0.1953-07812 \mathrm{mg} / \mathrm{mL}$ respectively, thus determining bacteriostatic activity. $100 \%$ of the germs tested were sensitive to hydroethanolic and ethanolic extracts. The inhibition diameters range from $12-28 \mathrm{~mm}$ for hydroethanolic extract with MIC and MBC or MFC ranging from $0.0488-0.3906 \mathrm{~mm}$ and $0.0488-0.7812 \mathrm{~mm}$ respectively. The ethanolic extract gave inhibition diameters of $12-26 \mathrm{~mm}$; MIC and MBC or MFC ranging from $0.0976-0.7812$
\end{abstract}


$\mathrm{mm}$. Hydroethanolic extract gave three (3) bactericidal/fungicidal activities compared to four (4) as for ethanolic extract. These results prove the use of $S$. aromaticum among traditional recipes for treating infections in the pharmacopoeia but further studies remain important to produce traditionally improved drugs.

\section{Subject Areas}

Pharmacology

\section{Keywords}

Syzygium aromaticum, Phytochemical, Antibacterial, Antifungal

\section{Introduction}

The traditional use of plants for health care by the peoples of the world dates back to ancient times. Nowadays, plants continue to be used as a cure for various diseases despite advances in modern medicine; this is due to the perpetual phenomena of resistance of microbial agents to conventional antibiotics and their side effects [1]. This situation not only leads the laboratories to look to the plants for the research of new active ingredients but also the populations to be attached to the medicinal plants which indeed are effective, having less side effects and accessible with affordable costs [1]. Moreover, the rationale for traditional medicine, which uses plants for health care, comes from the fact that in developing countries most people have low incoming power and access to health services is limited in some areas.. But these plants must be studied in order to establish the scientific evidence of their uses. For example, an ethnobotanical survey of sellers of alcoholic herbal infusions in Lomé city identified several plants which supposedly treat urinary, genital, throat and pulmonary infections. This work consisted on the one hand to map and then to identify all the plants used for the infused recipes and on the other hand to evaluate the antibiotic activity of some plants against the germs involved in the aforementioned pathologies. Among the listed plants is Syzygium aromaticum commonly known as clove. It is an evergreen aromatic plant 10 to $20 \mathrm{~m}$ tall belonging to the Myrtaceae family, native to the Maluku Islands of Eastern Indonesia [2] [3]. It is used in traditional medicine to deal with nausea and vomiting, cough, diarrhea, dyspepsia, flatulence, stomach distention and gastrointestinal spasms, pain, to cause uterine contraction and stimulate nerves [4] [5] [6]. Scientific research has shown that cloves have antimutagenic [7], antiulcer [8], antithrombotic, antioxidant [9] [10], anti-inflammatory [11], antiparasitic, antiseptic, antiviral and antimicrobial properties [3] [12]. With regard to antimicrobial studies, many germs are still to be tested in order to identify the spectrum of activity of the plant. It is in this perspective that this research aims to determine the susceptibility of reference germs and their clinical counterpart to $S$. aromaticum spices extracts. 


\section{Material and Methods}

The material consists of fruits (spices) of $S$. aromaticum, harvested in Tabligbo, Togo. The plant has been identified in the Laboratory of Botany and Plant Ecology of the Faculty of Sciences (FDS) of the University of Lomé (UL). A voucher specimen was deposited in the herbarium of this laboratory under the number TG15323. Then the fruits were washed and dried under air conditioning $\left(20^{\circ} \mathrm{C} \pm\right.$ $2^{\circ} \mathrm{C}$ ) in the laboratory of Physiology Pharmacology of the FDS. They were finally reduced to powder with a mortar for manual use, kept in sealed boxes protected from light for extraction and stored at room temperature.

The microorganisms consist of the reference strains and their clinical counterpart: Escherichia coli ATCC 25922, Escherichia coli, Staphylococcus aureus ATCC 29213, Staphylococcus aureus, Salmonella typhimurium ATCC 14028, Salmonella typhi, Pseudomonas aeruginosa ATCC 27853, Pseudomonas aeruginosa, Shigella flexneri ATCC 12022, Shigella flexneri, Candida albicans ATCC 35659 and Candida albicans. These germs come from the laboratory of bacteriology of the National Institute of Hygiene (INH) of Lomé except for Candida albicans ATCC 35659 which was provided by the Laboratory of Microbiology and Control of Foodstuffs (LAMICODA), ESTBA/UL. Clinical strains were isolated from urine (E. coli), pus (S. aureus, P. aeruginosa), stool (S. typhi, S. flexneri) and vaginal secretions (C. albicans) from patients (Figure 1 ).

\subsection{Methods}

\subsubsection{Phytochemical Screening}

Phytochemical compounds such as polyphenols, flavonoids, tannins, saponosides, terpenes, steroids, alkaloids, mucilages, coumarins, reducing compounds, anthocyanins, leucoanthocyanins, quinones and cyangenic derivatives, free anthracene derivatives and glycosides have been sought in plant powder using methods described by Harbon [13] and Wong et al. [14].

\subsubsection{Extraction}

$50 \mathrm{~g}$ of vegetable powder were macerated with $500 \mathrm{~mL}$ of ethanol $95^{\circ}$ for $24 \mathrm{~h}$ with stirring at $1600 \mathrm{rpm}$. The residue was taken up twice in $300 \mathrm{~mL}$ of ethanol $95^{\circ}$ before being rejected. For the hydroethanolic maceration the same technique was used with a water-ethanol mixture in equal volume $(\mathrm{v} / \mathrm{v})$. For the aqueous

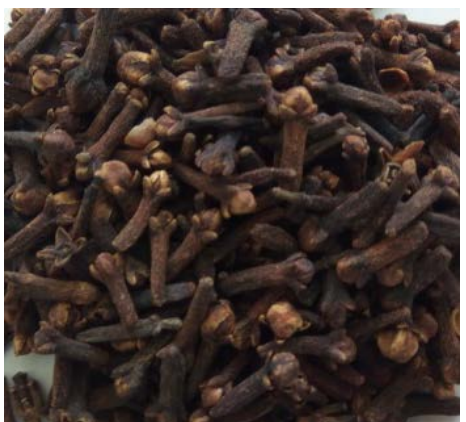

Figure 1. Fruits of Syzygium aromaticum. 
extract, a decoction was obtained from $50 \mathrm{~g}$ of vegetable powder boiled in 500 $\mathrm{mL}$ of distilled water for $30 \mathrm{~min}$. The decoction obtained was filtered hot on cotton and then cooled at room temperature. Decoction and macerates were then filtered through Wattman $\mathrm{N}^{\circ} 40$ filter paper. Each filtrate was then evaporated under vacuum at $40^{\circ} \mathrm{C}$ using an evaporator. The three extracts were stored at $-20^{\circ} \mathrm{C}$ until use.

\subsubsection{Antimicrobial Activities}

The germs collected were re-isolated on appropriate agar medium (Chapman for S. aureus, Eosin Blue Methylene (EMB) for E. coli, Hectoen for Salmonella and Shigella, Muller Hinton Agar (MHA) for Pseudomonas, Sabouraud chloramphenicol (SC) for C. albicans in order to obtain young colonies from 18 to $24 \mathrm{~h}$ which were used in the preparation of the inoculum. The tested extract solutions were prepared at a concentration of $200 \mathrm{mg} / \mathrm{mL}$ in distilled water and then sterilized on millipore membrane of $0.45 \mu \mathrm{m}$ porosity and $47 \mathrm{~mm}$ in diameter.

\section{1) Antibiotic susceptibility testing}

The antibiotic susceptibility testing was performed by the agar well diffusion method used by Karou et al. [15] with some changes. It is a presumptive test that has made it possible to identify the active extracts starting from a high concentration.

The microbial suspensions used were equal to 0.5 Mac Farland $\left(\approx 10^{8}\right.$ $\mathrm{CFU} / \mathrm{mL}$ ). They were quantified by the measurement of densitometer turbidity. The inoculum was introduced on culture medium prepared under standard conditions. These were MHA agar for bacteria and Casitone agar for Candida. The quality of these medium was evaluated by sterility and fertility tests before use. After inoculation of the medium, wells of $6 \mathrm{~mm}$ in diameter were made using a sterile hollow punch concentrically in the agar. Each well was flooded with $50 \mu \mathrm{L}$ of extract at a concentration $200 \mathrm{mg} / \mathrm{mL}$. Gentamicin solutions $10 \mu \mathrm{g}$ (for staphylococci, Enterobacteriaceae, and Pseudomonas) and Nystatin $100 \mu \mathrm{g}$ for C. albicans were used as reference drugs. For negative controls, sterile distilled water was used in place of the extract. After 30 minutes of pre-diffusion at laboratory temperature, the Petri dishes were incubated for 18 to $24 \mathrm{~h}$ at a temperature of $35^{\circ} \mathrm{C} \pm 2{ }^{\circ} \mathrm{C}$ for the bacteria and $25^{\circ} \mathrm{C} \pm 2{ }^{\circ} \mathrm{C}$ for the yeasts. The diameters of the microbial growth inhibition zones were measured using an electronic reading chart. Extracts having an inhibition diameter $\geq 12 \mathrm{~mm}$ (including disc) were used for the determination of MIC, MBC/MFC. The tests were repeated in triplicate.

2) Determination of Minimum Inhibitory Concentrations (MIC) and Bactericidal/Fungicidal (MBC/MFC)

The test for establishing the susceptibility curve was carried out for the extracts which gave a growth inhibition diameter of the seeds $\geq 12 \mathrm{~mm}$ with the previously performed antibiotic susceptibility testing (presumptive test). It was performed using the 96-well microplate dilution method [16] [17] [18]. From a stock solution of $200 \mathrm{mg} / \mathrm{mL}$ extract, a series of successive dilutions by geometric 
progression of reason 2 were made in Mueller Hinton Broth (MHB). The wells were inoculated with a microbial suspension at $6 \times 10^{5} \mathrm{CFU} / \mathrm{mL}$. Quality control was done with MHB (not inoculated). Another control was made with seeded MHB to facilitate reading. The tests were carried out under a Microbiological Safety Post (PSM). The preparations were covered with parafilm and then incubated at the appropriate temperature for $24 \mathrm{~h}$. After incubation, the wells were observed with the naked eye. The presence of turbidity or deposition corresponded to the presence of microbial culture. The well corresponding to the lowest concentration of extract for which no culture was observed represented the MIC of the extract on the strain tested. Then, from the MIC, $100 \mu \mathrm{L}$ were taken from wells that did not give microbial growth visible to the naked eye and then seeded on Plate Count Agar (PCA) medium for bacteria and SC agar for Candida. The incubation was carried out at the appropriate temperature for $24 \mathrm{~h}$. The lowest concentration for which no colony was considered as the MBC or MFC of the extract on the strain tested. The antibiotic potency of the extract on the microbial strain was determined by the MBC/MIC ratio. The tests were performed in triplicate [15] [18].

\subsubsection{Data Analysis}

The results were analyzed using Graph Pad Prism 6 software and then presented as the mean with standard deviation (Mean $\pm \mathrm{SD}$ ), $\alpha=0.05$.

\section{Results}

\subsection{Phytochemical Screening}

Phytochemical screening revealed the presence of alkaloids, gallic tannins, flavonoids, anthocyanins, saponosides, terpenes, steroids, coumarins, and reducing compounds. The catechoic tannins, the leucoanthocyanins, the quinones, the cyanogenic derivatives, the mucilages, the glycosides (free, O-, C- and cardiac) being absent (Table 1).

\subsection{Presumptive Testing}

The three extracts were active on all tested germs with growth inhibition diameters $\geq 12 \mathrm{~mm}$ except for the aqueous extract which gave a diameter of inhibition $<12 \mathrm{~mm}$ for salmonella and yeasts. In general, the growth inhibition diameters of the seeds range from 0 to $21 \mathrm{~mm}$ for the aqueous extract, from 12 to $28 \mathrm{~mm}$ for the hydroethanolic extract and from 0 to $26 \mathrm{~mm}$ for the ethanolic extract (Table 2 and Figure 2).

Table 1. Phytochemicals screening.

\begin{tabular}{|c|c|c|c|c|c|c|c|c|c|c|c|c|c|c|c|c|c|c|}
\hline Metabolites & $\mathrm{Al}$ & $\mathrm{Tac}$ & Tag & $\mathrm{Fl}$ & Ant & Leu & Qn & $\mathrm{Sp}$ & $\mathrm{Tp}$ & St & Cy & $\mathrm{Mu}$ & $\mathrm{Cm}$ & $\mathrm{Cr}$ & $\mathrm{Hl}$ & $\mathrm{O}-\mathrm{H}$ & $\mathrm{C}-\mathrm{H}$ & $\mathrm{Hc}$ \\
\hline S. aromaticum & + & - & + & + & + & - & - & + & + & + & - & - & + & + & - & - & - & - \\
\hline
\end{tabular}


Table 2. Susceptibility of microorganisms to extracts.

\begin{tabular}{|c|c|c|c|c|c|c|}
\hline \multirow{2}{*}{ Microorganisms } & \multicolumn{3}{|c|}{ S. aromaticum extracts } & \multicolumn{2}{|c|}{ Positive contols } & \multirow{2}{*}{$\begin{array}{c}\text { Negative control } \\
\qquad \mathrm{H}_{2} \mathrm{O}\end{array}$} \\
\hline & Aqueous & HydroEtOH & $\mathrm{H}_{2} \mathrm{O}$ & Gentamicin & Nystatin & \\
\hline Escherichia coli ATCC 25922 & $16 \pm 0$ & $18 \pm 0$ & $12 \pm 1$ & $16 \pm 0$ & NA & $0 \pm 0$ \\
\hline Escherichia coli & $15 \pm 1$ & $17 \pm 0$ & $14 \pm 0$ & $14 \pm 0$ & NA & $0 \pm 0$ \\
\hline Staphylococcus aureus ATCC 29213 & $19 \pm 0$ & $22 \pm 0$ & $26 \pm 0$ & $24 \pm 0$ & NA & $0 \pm 0$ \\
\hline Staphylococcus aureus & $20 \pm 0$ & $21 \pm 0$ & $22 \pm 0$ & $17 \pm 0$ & NA & $0 \pm 0$ \\
\hline Salmonella typhimurium ATCC 14028 & $9 \pm 0$ & $12 \pm 0$ & $14 \pm 0$ & $16 \pm 0$ & NA & $0 \pm 0$ \\
\hline Salmonella typhi & 0.00 & $17 \pm 1$ & $16 \pm 0$ & $18 \pm 1$ & NA & $0 \pm 0$ \\
\hline Pseudomonas aeruginosa ATCC 27853 & $13 \pm 0$ & $19 \pm 1$ & $14 \pm 0$ & $15 \pm 0$ & NA & $0 \pm 0$ \\
\hline Pseudomonas aeruginosa & $15 \pm 0$ & $14 \pm 0$ & $14 \pm 0$ & $15 \pm 0$ & NA & $0 \pm 0$ \\
\hline Shigella flexneri ATCC 12022 & $21 \pm 1$ & $22 \pm 0$ & $14 \pm 0$ & $15 \pm 0$ & NA & $0 \pm 0$ \\
\hline Shigella flexneri & $21 \pm 0$ & $22 \pm 0$ & $24 \pm 0$ & $15 \pm 0$ & NA & $0 \pm 0$ \\
\hline Candida albicans ATCC 35659 & $0 \pm 0$ & $27 \pm 1$ & $17 \pm 0$ & NA & $16 \pm 1$ & $0 \pm 0$ \\
\hline Candida albicans & $0 \pm 0$ & $28 \pm 0$ & $21 \pm 0$ & NA & $17 \pm 1$ & $0 \pm 0$ \\
\hline
\end{tabular}

HydroEtOH: Hydroethanolic; Et-OH: Ethanolic; NA: Not applicable.

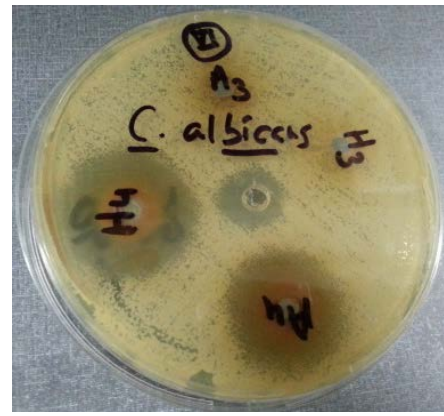

(a)

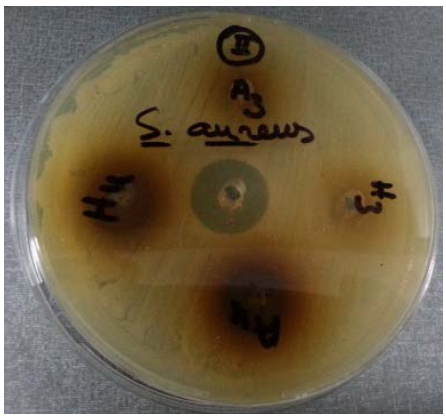

(c)

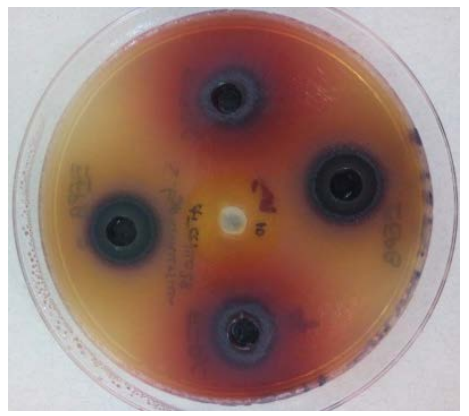

(b)

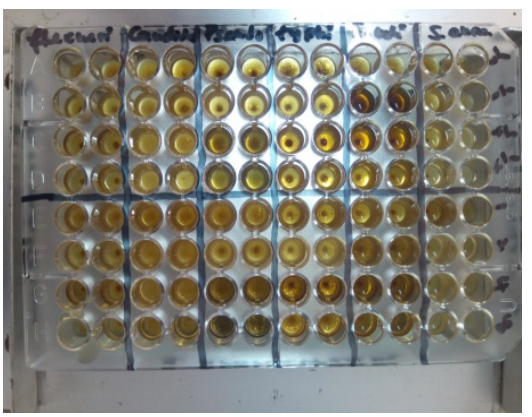

(d)

Figure 2. Typical images showing the inhibition zones. (a) Effects of hydroethanolic extract (H4) and aqueous extract (A4) against C. albicans; (b) Effect of ethanolic extract against $S$. typhimurium; (c) Effects of hydroethanolic extract $(\mathrm{H} 4)$ and aqueous extract (A4) against $S$. aureus; (d) Determination of MIC in microplate.

\subsection{Microbicidal Activity}

MICs and MBCs/MFCs were determined for germs that were susceptible to ex- 
tracts with inhibition diameters $\geq 12 \mathrm{~mm}$. The bacteriostatic and bactericidal effects of the extracts on the germs were determined by the ratio of $\mathrm{MBC} / \mathrm{MIC}$ or MFC/MIC $\leq 1$ (Bactericidal); MBC/MIC or MFC/MIC $\geq 2$ (Bacteriostatic). The results are compiled in Table 3.

MICs of the aqueous extract ranged from 0.0976 to $0.3906 \mathrm{mg} / \mathrm{mL}$ for both reference and clinical microorganisms with some differences for some strains. MBC and MFC are twice as high as MICs for both germ types; which gave a ratio of $\mathrm{MBC} / \mathrm{MIC}$ or MFC/MIC $=2$ for the aqueous extract. For the hydroethanolic extract, the MICs and MBCs or MFCs are between 0.0488 and $0.7812 \mathrm{mg} / \mathrm{mL}$ and the $\mathrm{MBC} / \mathrm{MIC}$ or $\mathrm{MFC} / \mathrm{MIC}$ ratio $=2$ for most germs; only three germs $(E$. coli ATCC 25922, S. typhimurium ATCC 14028, C. albicans ATCC 35659) had their $\mathrm{MBC} / \mathrm{MIC}$ or $\mathrm{MFC} / \mathrm{MIC}=1$. The microorganisms were also sensitive to the ethanolic extract with MIC and MBC/MFC between 0.0976 and $0.7812 \mathrm{mg}$ $/ \mathrm{mL}$. Four germs showed a MBC/MIC or $\mathrm{MFC} / \mathrm{MIC}=1$ ratio; this ratio is greater than or equal to 2 for the other germs and even 4 for $S$. flexneri. All clinical strains were inhibited with concentrations equal to or greater than those corresponding to inhibition of standard germs.

\section{Discussion}

The study of the antimicrobial activity of $S$. aromaticum made it possible to determine the sensitivity of E. coli ATCC 25922, S. aureus ATCC 29213, S. typhimurium ATCC 14028, P. aeruginosa ATCC 27853, S. flexneri ATCC 12022, C. albicans ATCC 35659 and their clinical counterpart (E. coli, S. aureus, S. typhi, $P$. aeruginosa, $S$. flexneri, $C$. albicans) to aqueous, hydroethanolic and ethanolic extracts. The aqueous extract inhibited approximately $66.67 \%$ of tested germs

Table 3. MIC and MBC of microorganisms.

\begin{tabular}{|c|c|c|c|c|c|c|c|c|c|}
\hline \multirow{2}{*}{ Reference germs } & \multicolumn{3}{|c|}{ Aqueous } & \multicolumn{3}{|c|}{ HydroEtOH } & \multicolumn{3}{|c|}{ Et-OH } \\
\hline & CMI & $\begin{array}{c}\mathrm{MBC} / \mathrm{MFC} \\
(\mathrm{mg} / \mathrm{mL})\end{array}$ & $\begin{array}{l}\mathrm{MBC} / \mathrm{CMI} \\
\mathrm{MFC} / \mathrm{CMI}\end{array}$ & CMI & $\begin{array}{c}\mathrm{MBC} / \mathrm{MFC} \\
(\mathrm{mg} / \mathrm{mL})\end{array}$ & $\begin{array}{l}\mathrm{MBC} / \mathrm{CMI} \\
\mathrm{MFC} / \mathrm{CMI}\end{array}$ & CMI & $\begin{array}{c}\mathrm{MBC} / \mathrm{MFC} \\
(\mathrm{mg} / \mathrm{mL})\end{array}$ & $\begin{array}{l}\mathrm{MBC} / \mathrm{CMI} \\
\mathrm{MFC} / \mathrm{CMI}\end{array}$ \\
\hline Escherichia coli ATCC 25922 & 0.0976 & 0.1953 & 2 & 0.0976 & 0.0976 & 1 & 0.0976 & 0.1953 & 2 \\
\hline Escherichia coli & 0.0976 & 0.1953 & 2 & 0.0976 & 0.1953 & 2 & 0.0976 & 0.1953 & 2 \\
\hline Staphylococcus aureus ATCC 29213 & 0.0976 & 0.1953 & 2 & 0.0976 & 0.1953 & 2 & 0.0976 & 0.0976 & 1 \\
\hline Staphylococcus aureus & 0.0976 & 0.1953 & 2 & 0.0976 & 0.1953 & 2 & 0.0976 & 0.1953 & 2 \\
\hline Salmonella typhimurium ATCC 14028 & - & - & - & 0.1953 & 0.1953 & 1 & 0.3906 & 0.7812 & 2 \\
\hline Salmonella typhi & - & - & - & 0.1953 & 0.7812 & 2 & 0.3906 & 0.7812 & 2 \\
\hline Pseudomonas aeruginosa ATCC 27853 & 0.3906 & 0.7812 & 2 & 0.3906 & 0.7812 & 2 & 0.3906 & 0.3906 & 1 \\
\hline Pseudomonas aeruginosa & 0.3906 & 0.7812 & 2 & 0.3906 & 0.7812 & 2 & 0.7812 & 0.7812 & 1 \\
\hline Shigella flexneri ATCC 12022 & 0.0976 & 0.1953 & 2 & 0.0976 & 0.1953 & 2 & 0.0976 & 0.3906 & 4 \\
\hline Shigella flexneri & 0.3906 & 0.7812 & 2 & 0.3906 & 0.7812 & 2 & 0.1953 & 0.3906 & 2 \\
\hline Candida albicans ATCC 35659 & - & - & - & 0.0488 & 0.0488 & 1 & 0.0976 & 0.0976 & 1 \\
\hline Candida albicans & - & - & - & 0.0488 & 0.0976 & 2 & 0.0976 & 0.1953 & 2 \\
\hline
\end{tabular}


while the hydroethanolic and ethanolic extract inhibited all the germs (100\%). The germs were totally susceptible to the reference drugs.

E. coli ATCC 25922 and E. coli clinical strain were susceptible to aqueous, hydroethanolic and ethanolic extracts with inhibition diameters ranging from 12 to $18 \mathrm{~mm}$. The largest diameters were found with the hydroethanolic extract; diameters that are greater than those given by Gentamicin used as a reference drug. The MICs and MBCs of the aqueous and ethanolic extracts on the reference strain and the clinical strain are identical, but with $\mathrm{MBC}=2 \mathrm{MIC}$; gving a ratio $\mathrm{MBC} / \mathrm{MIC}=2$ and determining bacteriostatic activity of these extracts on the two strains of E. coli. As for the hydroethanolic extract, the MICs and MBCs are identical to the previous ones on the clinical strain, but on the standard strain, the MIC is equal to the MBC and consequently, $\mathrm{MBC} / \mathrm{MIC}=1$ determining its bactericidal activity. Alharbi et al. [3] previously investigated the antimicrobial activity of $S$. aromaticum; but their study focused on the essential oils of the plant. According to their study, the pure oil of $S$. aromaticum inhibited the clinical strains of E. coli with MICs between 2.5 and $3.75 \mu \mathrm{g} / \mathrm{mL}$ and MBCs between 5.0 and $7.5 \mu \mathrm{g} / \mathrm{mL}$; giving a bacteriostatic activity. Jimoh et al. [19] found instead a bactericidal activity of essential oils of the plant with a growth inhibition diameter of around $28 \mathrm{~mm}$ and MICs and MBCs of $5 \mu \mathrm{L} / \mathrm{mL}$. The essential oil of the plant also gave growth inhibition of $E$. coli ATCC 25922 up to $14 \mathrm{~mm}$ in diameter at a concentration of $25 \mathrm{mg} / \mathrm{mL}$ [20]. These data confirm the antibacterial activity of our three brut extracts (aqueous, hydroethanolic, ethanolic) which gave a bacteriostatic activity on the clinical and standard strains of E. coli.

S. aureus ATCC 29213 and $S$. aureus were also sensitive to aqueous, hydroethanolic and ethanolic extracts with growth inhibition diameters ranging from 19 to $26 \mathrm{~mm}$. The aqueous extract gave the best growth inhibition diameters that are even higher than those of the standard drug (Gentamicin). With the three extracts, the $\mathrm{MBC}=2 \mathrm{MBC}$ on both $S$. aureus strains except for the aqueous extract which gave a MBC $=$ MIC on the reference strain. The aqueous extract therefore has a bactericidal activity on $S$. aureus ATCC 29213 and bacteriostatic on the clinical strain. The effect of the other two extracts is bacteriostatic on both strains. Other studies carried out on $S$. aromaticum have shown that the pure oil of the plant has a bacteriostatic activity on strains of $S$. aureus Meti-R with MICs and MBCs respectively of $0.625-1.25 \mu \mathrm{g} / \mathrm{mL}$ and $1.25-2.50 \mu \mathrm{g} / \mathrm{mL}$ [3]. Bactericidal activity of the essential oil of the plant was found by Jimoh et al. [19], which obtained an inhibition diameter of $30 \mathrm{~mm}$ and a MIC and MBC of 5 $\mu \mathrm{l} / \mathrm{mL}$ on the seed. Saikumari et al. [21] studied the essential oil and the methanolic extract of $S$. aromaticum which gave inhibition diameters of $14 \mathrm{~mm}$ and 16 $\mathrm{mm}$ respectively at the concentration of $100 \mu \mathrm{l} / \mathrm{mL}$. These same activities were found with our extracts. According to the study of Mohamed and Badri [20], the essential oil of the plant inhibits the growth of $S$. aureus ATCC 25923 with an inhibition diameter of $16 \mathrm{~mm}$ at a concentration of $25 \mathrm{mg} / \mathrm{mL}$. 
The actions of the aqueous, hydroethanolic and ethanolic extracts were irregular on S. typhimurium ATCC 14028 and S. typhi. Inhibition diameters of the aqueous extract on both strains are less than $12 \mathrm{~mm}$; for this purpose it is considered inactive. The active extracts (hydroethanolic and ethanolic) have a growth inhibition diameter of between 12 and $17 \mathrm{~mm}$; these diameters are smaller than those of Gentamicin used as a reference drug. The MICs and MBCs of the ethanolic extract are identical and the $\mathrm{MBC}=2 \mathrm{MIC}$; by deduction, $\mathrm{MBC} / \mathrm{MIC}=2$, thus showing a bacteriostatic activity. The hydroethanolic extract has a bacteriostatic activity on the clinical strain and a bactericidal activity on the standard strain. The hydroethanolic extract was active against the both strains. Mohamed and Badri [20], by studying the antimicrobial activity of the plant on the reference strains showed that the essential oil of $S$. aromaticum inhibits the growth of S. typhi ATCC 6539 with a diameter of $15 \mathrm{~mm}$ at the concentration $25 \mathrm{mg} / \mathrm{mL}$. This highlights the antibacterial activity of $S$. aromaticum on Salmonella strains.

The effect of extracts on $P$. aeruginosa ATCC 27853 and its clinical counterpart $P$. aeruginosa was significant compared to that of Gentamicin with inhibition diameters between 13 and $19 \mathrm{~mm}$. The ethanolic extract was more active with inhibition diameters greater than those of the reference drug. The MICs are the same except for the ethanol extract, which has a higher MIC on the clinical strain. The $\mathrm{MBC}=2 \mathrm{MIC}$ except for the ethanolic extract whose $\mathrm{MIC}=\mathrm{MBC}$ on the reference strain. It appears that the ethanolic extract has a bactericidal activity on $P$. aeruginosa ATCC 27853 and bacteriostatic on $P$. aeruginosa clinical strain. The aqueous and hydroethanolic extracts showed bacteriostatic activity on both clinical strains. The study of the antibacterial activity of pure oils of $S$. aromaticum on the clinical $P$. aeruginosa strains conducted by Alharbi et al. [3] proves the bacteriostatic and bactericidal effect of our brut extracts on $P$. aeruginosa. They showed that the pure oil of $S$. aromaticum inhibits $P$. aeruginosa with MICs and MBCs ranging from $0.3125-0.625 \mu \mathrm{g} / \mathrm{mL}$ and $0.625-0.9375$ $\mu \mathrm{g} / \mathrm{mL}$ respectively and giving the bacteriostatic activity of the oil. Jimoh et al. [19] also reported the bacteriostatic activity of the essential oil of the plant which inhibits the growth of $P$. aeruginosa with a diameter of $21 \mathrm{~mm}$ and a MIC of 9 $\mu \mathrm{L} / \mathrm{mL}$. The literature review also showed that the reference strain, $P$. aeruginosa ATCC 27853 was sensitive to the essential oil of $S$. aromaticum with a zone of growth inhibition equal to $16 \mathrm{~mm}$ in diameter at the concentration of $50 \mathrm{mg} / \mathrm{mL}$ [20], thus attesting the antibacterial activity of the plant on the $P$. aeruginosa standard strain.

Shigella were also responding to the aqueous, hydroethanolic and ethanolic extracts of the plant. S. flexneri ATCC 12022 and S. flexneri were sensitive to all three extracts with growth inhibition diameters ranging from 14 to $24 \mathrm{~mm}$. Both strains of Shigella were also susceptible to Gentamicin. The extracts all gave a bacteriostatic activity on the two strains with a ratio $\mathrm{MBC} / \mathrm{MIC}=2$ and 4 exceptionally for the ethanolic extract on the standard strain. In general, the hydroethanolic extract was more active. 
The yeasts showed resistance to the aqueous extract. C. albicans ATCC 35659 and $C$. albicans, clinical strain was sensitive to hydroethanolic and ethanolic extracts with inhibition diameters between 17 and $28 \mathrm{~mm}$. Both strains were also susceptible to Nystatin as a standard. The hydroethanolic and ethanolic extracts gave a fungicidal activity on the standard and fungistatic strain on the clinical strain. The MICs of the ethanolic extract on Candida were lower than those observed with bacteria. Other studies by Mohamed and Badri [20] revealed the antifungal activity of the essential oil of the plant on $C$. albicans ATCC 7596. The results of their studies showed that the yeast was susceptible with a diameter of inhibition of $20 \mathrm{~mm}$ at the concentration of $12.5 \mathrm{mg} / \mathrm{mL}$. Jimoh et al. [19] showed that the essential oil of $S$. aromaticum has bacteriostatic activity on $C$. albicans with an inhibition diameter of up to $44 \mathrm{~mm}$ and a MIC of $1 \mu \mathrm{L} / \mathrm{mL}$. This confirms the antifungal activity of our hydroethanolic and ethanolic extracts.

Phytochemical compounds (alkaloids, tannins, flavonoids, anthocyanins, saponosides, terpenes, steroids, coumarins, reducing compounds) found in the fruits of $S$. aromaticum have been proven by some authors [19]. The antimicrobial activity observed with the aqueous extracts, hydroethanolic and ethanolic would be at the origin of one or more of these phytochemical compounds which would have acted alone or in synergy. Eugenol, a phytochemical compound mainly found in clove and already known for its antibacterial and antifungal activity, may be responsible for the observed antimicrobial activity [22] [23]. In fact, the alkaloids, saponosides, flavonoids and tannins in the fruits of the plant are known to have a curative activity against several pathogenic agents: $S$. aureus, E. coli, P. aeruginosa and C. albicans [19] [24]. The action mechanism of tannins is complexation either with enzymes or with bacterial substrates or with metal ions or its action on the cell membrane of bacteria [18] [25]. Tannins are known to have inhibitory activities on the growth of $S$. aureus and $P$. aeruginosa [26]. Flavonoids cause lysis of the membrane and consequently death of the cell [18] [27]. These mechanisms of action of tannins and flavonoids could partly explain the bactericidal and bacteriostatic effects given by the aqueous, hydroethanolic and ethanolic extracts of $S$. aromaticum on the tested microorganisms.

\section{Conclusion}

This study confirmed the antimicrobial activity of $S$. aromaticum fruits used in the treatment of infections by practitioners of traditional medicine. The sensitivity tests carried out on the reference strains and their clinical counterpart showed that the hydroethanolic extract was very active on all these tested germs and it would therefore be desirable to extend the tests to multidrug-resistant germs. The antimicrobial activity of aqueous extracts, hydroethanolic and ethanolic observed could be related to certain phytochemical compounds contained in the fruits of the plant. Furthermore, studies on the determination of the physicochemical constants, pharmacokinetics, pharmacodynamics and toxicity of 
the extracts must be pursued in order to produce traditionally improved medicinal products to replace alcoholic herbal infusions of medicinal plants since the alcohol exerts toxicity on the organism.

\section{Acknowledgements}

Our thanks to the National Institute of Hygiene (INH) of Lomé, Laboratory of Microbiology and Foodstuffs (LAMICODA) of ESTBA, UL.

\section{Conflicts of Interest}

No conflict of interest.

\section{References}

[1] Atchou, K., Agban, A., Batawila, K., Karou, S.D., Tchacondo, T., Amadou, S.H., de Souza, C., Gbeassor, M. and Akpagana, K. (2013) Effets antimicrobiens de Lannea kerstingii Engl. et K. Krause (Anacardiaceae). Revue Africaine de Santé et de Productions Animales, 11, 121-124.

[2] Reji, R. and Rajasekaran, M. (2015) Evaluation of Synergistic Antimicrobial Activity of Cinnamomum zeylancium, Trachyspermum ammi and Syzygium aromaticum. International Journal of Pharmaceutical Sciences and Research, 6, 304-311.

[3] Alharbi, A.A. (2017) Antibacterial Activities of Syzygium aromaticum Oil against Local Clinical Pathogenic bacteria. International Journal of International Studies in Sciences and Engineering Technology, 3, 7-11.

[4] Elujoba, AA., Odeleye, O.M. and Ogunyemi, C.M. (2005) Traditional Medicine Development for Medical and Dental Primary Health Care Delivery System in Africa. African Journal of Traditional, Complementary and Alternative Medicines, 2, 46-61.

[5] Sulieman, A.M.E., El Boshra, I.M.O. and El Khalifa, E.A.A. (2007) Nutritive Value of Clove (Syzygium aromaticum) and Detection of Antimicrobial Effect of Its Bud Oil. Research Journal of Microbiology, 2, 266-271. https://doi.org/10.3923/jm.2007.266.271

[6] Tanko, Y., Mohammed, A., Okasha, M.A., Umar, A.H. and Magaji, R.A. (2008) Anti-Nociceptive and Anti-Inflammatory Activities of Ethanol Extract of Syzygium aromaticum Flower Bud in Wistar Rats and Mice. African Journal of Traditional, Complementary and Alternative Medicines, 5, 209-212. https://doi.org/10.4314/ajtcam.v5i2.31275

[7] Miyazawa, M. and Hisama, M. (2003) Antimutagenic Activity of Phenyl Propanoides from Clove (Syzygium aromaticum). Journal of Agriculture and Food Chemistry, 5, 6413-6422. https://doi.org/10.1021/jf030247q

[8] Li, Y., Xu, C., Zhang, Q., Liu, J.Y. and Tan, R.X. (2005) In Vitro Anti-Helicobacter pylori Action of 30 Chinese Herbal Medicines Used to Treat Ulcer Diseases. Journal of Ethnopharmacology, 98, 329-333. https://doi.org/10.1016/j.jep.2005.01.020

[9] Chaieb, K., Zmantar, T., Ksouri, R., Hajlaoui, H., Mahdouani, K., Abdelly, C. and Bakhrouf, A. (2007) Antioxidant Properties of Essential Oil of Eugenia caryophyllata and Its Antifungal Activity against a Large Number of Clinical Candida Species. Mycoses, 50, 403-406. https://doi.org/10.1111/j.1439-0507.2007.01391.x

[10] Saeed, S. and Tariq, P. (2008) In Vitro Antibacterial Activity of Clove against Gram Negative Bacteria. Pakistan Journal of Botany, 40, 2157-2160. 
[11] Srivastava, K.C. and Malhotra, N. (1991) Acetyl Euginol, a Component of Oil of Cloves (Syzygium aromaticum L.) Inhibits Aggregation and Alters Arachidonic Acid Metabolism in Human Blood Platelets. Prostaglandins, Leukotrienes and Essential Fatty Acids, 42, 73-81. https://doi.org/10.1016/0952-3278(91)90070-L

[12] Park, M.J., Gwak, K.S., Yang I., Choi, W.S., Jo, H.J., Chang, J.W., Jeung, E.B. and Choi, I.G. (2007) Antifungal Activities of the Essential Oils in Syzygium aromaticum (L.) Merr. Et Perry and Leptospermum betersonni Bailey and Their Constituents against Various Dermatophytes. Journal of Microbiology, 45, 460-465.

[13] Harbone, J.B. (1973) Phytochemical Methods. Chapman and Hall, New York, 354 p.

[14] Wong, C.C., Li, H.B., Cheng, K.W. and Chen, F.A. (2006) Systematic Survey of Antioxidant Activity of 30 Chinese Medicinal Plants Using the Ferric Reducing Antioxidant Power Assay. Food Chemestry, 97, 705-711.

https://doi.org/10.1016/j.foodchem.2005.05.049

[15] Karou, D., Dicko, M.H., Simpore, J. and Traore, A.S. (2005) Antioxidant and Antibacterial Activities of Polyphenols from Ethnomedicinal Plants of Burkina Faso. African Journal of Biotechnology, 4, 823-828.

[16] Kpadonou, K.B.G.H., Yayi, L.E., Kpoviessi, D.S.S., Gbaguidi, F., Yèhouénou, B., Quetin-Leclercq, J., Figueredo, G., Moudachirou, M. and Accrombessi, G.C. (2012) Chemical Variation of Essential Oil Constituents of Ocimum gratissimum L. from Benin, and Impact on Antimicrobial Properties and Toxicity against Artemia salina LEACH. Chemistry and Biodiversity, 9, 139-150. https://doi.org/10.1002/cbdv.201100194

[17] Yehouenou, B., Ahoussi, E., Sessou, P., Alitonou, G.A., Toukourou, F. and Sohounhloue, D.C.K. (2012) Chemical Composition and Antimicrobial Activities of Essential (EO) Extracted from Leaves of Lippia rugose A. Chev. against Foods Pathogenic and Adulterated Microorganisms. African Journal of Microbiology Research, 6, 5496-5505.

[18] Anani, K., Adjrah, Y., Ameyapoh, Y., Karou, S.D., Agbonon, A., de Souza, C. and Gbeassor, M. (2016) Antimicrobial, Anti-Inflammatory and Antioxidant Activities of Jatropha multifida L. (Euphorbiaceae). Pharmacognosy Research, 8, 142-146. https://doi.org/10.4103/0974-8490.172657

[19] Jimoh, S.O., Arowolo, L.A. and Alabi, K.A. (2017) Phytochemical Screening and Antimicrobial Evaluation of Syzygium aromaticum Extract and Essential Oil. International Journal of Current Microbiology and Applied Sciences, 6, 4557-4567. https://doi.org/10.20546/ijcmas.2017.607.476

[20] Mohamed, S.G. and Badri A.M. (2017) Antimicrobial Activity of Syzygium aromaticum and Citrus aurantifolia Essential Oils against Some Microbes in Khartoum, Sudan. EC Microbiology, 12, 253-259.

[21] Saikumari, D., Shiva Rani, S.K. and Saxena, N. (2016) Antibacterial Activity of Syzygium aromaticum L. (Clove). International Journal of Current Microbiology and Applied Sciences, 5, 484-489. https://doi.org/10.20546/ijcmas.2016.511.056

[22] Suresh, P., Ingle, V.K. and Vijayalakshmi, V. (1992) Antibacterial Activity of Eugenol in Comparison with Other Antibiotics. Journal of Food Science and Technology, 29, 256-257.

[23] Tampieri, M.P., Galuppi, R., Macchioni, F., Carelle, M.S., Falcioni, L., Cioni, P.L. and Morelli, I. (2005) The Inhibition of Candida albicans by Selected Essential Oils and Their Major Components. Mycopathologia, 159, 339-345. https://doi.org/10.1007/s11046-003-4790-5

[24] Usman, H. and Osuji, J.C. (2007) Phytochemical and in Vitro Antimicrobial Assay 
of the Leaf Extract of Newbouldia laevis. African Journal of Traditional, Complementary and Alternative Medicines, 4, 476-480.

https://doi.org/10.4314/ajtcam.v4i4.31240

[25] Banso, A. and Adeyemo, S.O. (2007) Evaluation of Antibacterial Properties of Tannins Isolated from Dichrostachys cinerea. African Journal of Biotechnology, 6, 1785-1787. https://doi.org/10.5897/AJB2007.000-2262

[26] Akiyama, H., Fujii, K., Yamasaki, O., Oono, T. and Iwatsuki, K. (2001) Antibacterial Action of Several Tannins against Staphylococcus aureus. Journal of Antimicrobial Chemotherapy, 48, 487-491. https://doi.org/10.1093/jac/48.4.487

[27] Aransiola, M.N., Ehikhase, C., Mmegwa, J.C. and Wahab, I.O. (2014) Antibacterial and Antifungal Activities of Jatropha multifida (Ogege) Sap against Some Pathogens. IOSR Journal of Pharmacy and Biological Sciences, 9, 53-57.

https://doi.org/10.9790/3008-09415357 